\title{
Assessment of Physicochemical and Selected Heavy Metal of Soil around Dana Steel Industry Limited Katsina, Katsina State, Nigeria
}

\author{
S. A. Zauro ${ }^{1,2^{*}}$, A. Muhammad ${ }^{1}$, K. J. Umar ${ }^{3}$, I. Abubakar ${ }^{3}$, Y. M. Sani ${ }^{3}$, \\ K. Bello ${ }^{4}$ and A. A. Isah \\ ${ }^{1}$ Department of Pure and Applied Chemistry, Usmanu Danfodiyo University, P.M.B. 2346, Sokoto, \\ ${ }^{2}$ Department of Post-graduate Studies and Research in Chemistry, Mangalore Unigeria. \\ 574199 Mangalore, Karnataka, India. \\ ${ }^{3}$ Department of Pure and Industrial Chemistry, Federal University Birnin-Kebbi, P.M.B. 1157, \\ Birnin Kebbi, Nigeria. \\ ${ }^{4}$ Chemistry Unit, Department of Natural Sciences, Umaru Ali Shinkafi Polytechnic, Sokoto, Nigeria.
}

\section{Authors' contributions}

This work was carried out in collaboration between all authors. Authors SAZ and AM designed the study, performed the laboratory experiment and wrote the first draft of manuscript. Authors KJU, AAI and $K B$ designed the experiment and carried out the statistical analysis. Authors IA and YMS managed the literature searches. All authors read and approved the final manuscript.

\section{Article Information}

DOI: $10.9734 /$ AJOCS/2017/34029

Editor(s):

(1) Georgiy B. Shul'pin, Semenov Institute of Chemical Physics, Russian Academy of Sciences, Moscow, Russia. Reviewers:

(1) Abida Begum, P. E. S. School of Engineering, Bangalore, India. (2) Mohammad H. Golabi, University of Guam, Mangilao, USA. (3) Awokunmi Emmanuel Eyitayo, Ekiti State University, Ado Ekiti, Nigeria. Complete Peer review History: http://www.sciencedomain.org/review-history/19333

Original Research Article

Received $9^{\text {th }}$ May 2017 Accepted $30^{\text {th }}$ May 2017 Published $3^{\text {rd }}$ June 2017

\section{ABSTRACT}

The physicochemical parameters and levels of selected heavy metals $(\mathrm{Cd}, \mathrm{Cr}, \mathrm{Mn}, \mathrm{Zn}$ and $\mathrm{Pb})$ in soil around Dana Steel Rolling Limted Katsina were investigated in this research. The sample area was divided into four units; East, West, North and South and label as A, B, C and D respectively using stratified random sampling method. The soil was digested using $\mathrm{H}_{2} \mathrm{SO}_{4}, \mathrm{HClO}_{4}$ and $\mathrm{HNO}_{3}$ for 15 minutes and filtered. The filtrate was used for the analysis using Atomic Absorption 
Spectrophotometer. The results obtained showed that the sampling area is mildly alkaline with $\mathrm{pH}>7.0$. Low moisture and organic matter was also observed in the entire sampling site. For the heavy metals contents, the results indicated that the area under investigation was not polluted with respect to heavy metals content. As the metals content investigated were all below the US EPA standard of heavy metals in soils that requires clean up.

Keywords: Soil; heavy metals; Dana steel; environment; physicochemical.

\section{INTRODUCTION}

One of the most serious problems facing humanity and other forms of life on earth now is environmental pollution [1]. Understanding soil pollutants and their dependence on its physicochemical properties has provides a basis for careful soil management that limits as far as possible the negative impact of the pollutants on the ecosystem. Soil contaminated with heavy metals is poor in nutrients and contribute to suboptimal plant biomass accumulation [2].

Heavy metals are naturally occurring elements that have a high atomic weight and a density at least 5 times greater than that of water. Their multiple industrial, domestic, agricultural, medical and technological applications have led to their wide distribution in the environment; Raising concerns over their potential effects on human health and the environment. Their toxicity depends on several factors including the dose, route of exposure, and chemical species, as well as the age, gender, genetics, and nutritional status of exposed individual [3]. Heavy metals exist in colloidal, ionic, particulate, and dissolved phases. They are present in soil as free metal ions, soluble metal complexes, exchangeable metal ions, and organically bound metals, precipitated or insoluble compounds like oxides, carbonates, and hydroxides, silicate materials [4]. Metals are natural constituents of soil. They persist in soils and have a very slow leaching rate; hence they tend to accumulate in soils. Trace amount of some heavy metals are required by living organisms but in excess they are detrimental. The eco-toxicological risks of metal contamination bear potential harm for plants, animals and human. Heavy metals pollution can suppress or even kill sensitive parts of plant and soil microbial communities and lead to a shift in their functional diversity and structure. The release of metals into the soil is a concern to the environment. Since these metals might be release from soil solid phase to soil solution particularly under different conditions and eventually transferred to the human via food chain, thereby posing a hazard to environment and human health [5].
Once they are accumulated in the food chain, their effect gets adverse with tropic levels due to biomagnification. On the other hand, heavy metals like $\mathrm{Cu}, \mathrm{Fe}, \mathrm{Mn}, \mathrm{Ni}$, and $\mathrm{Zn}$ are essential for plant growth and are important constituents of many enzymes. In addition, metals like Al, As, $\mathrm{Cd}, \mathrm{Cr}, \mathrm{Hg}, \mathrm{Pb}, \mathrm{Sb}, \mathrm{Se}$, among others are nonessential and toxic above certain threshold levels [6].

Soils vary across the landscape, therefore each soil contains unique trace element concentrations based on its parent material and other soil-forming factors that may have added or removed these elements from the soil. High background concentrations of trace elements, whether natural or anthropogenic, could result in mobilization and release into surface and subsurface waters and subsequent incorporation into the food chain. Soil factors such as organic matter, type and amount of clay, $\mathrm{pH}$ and cation exchange capacity (CEC) influence the quantity of trace elements available for mobilization and release or sorption in a soil. The extent of soil pollution by heavy metals and base metal ions some of which are soil micronutrients is very alarming [7].

In Nigeria today, numerous studies indicated that industrial activities release heavy metals either as solid, gas and most especially liquids in the form of waste water or effluents allowed draining into water ways or bodies. Small scale road side activities are also significantly contributing to the transmission of these toxic species [8]. Joel and Amajuoyi [9], investigated the physicochemical parameters and heavy metals contents of a Drilling Cutting Dump Site at Ezeogwu-Owaza, Nigeria and reported that some of the metal like $\mathrm{Cu}, \mathrm{Fe}$ and $\mathrm{Ca}$ showed high level of contamination.

Tijjani et al. [10], studied the heavy metal contents in soil of Rimi local government in Katsina state using AAS and reported that the levels of the metals $(\mathrm{Cr}, \mathrm{Fe}, \mathrm{K}, \mathrm{Mg}, \mathrm{Na}, \mathrm{Pb}$ and $\mathrm{Zn}$ ) investigated were generally below the maximum permissible level for normal agricultural land practices. 
Based on the available literature, little or no work has been done to ascertain the extent of pollution in terms of heavy metals content in soil around Dana Steel Limited Katsina, Katsina State, Nigeria despite the fact that the area is an Industrial layout. Hence, we attempt to bridge that gap.

\section{MATERIALS AND METHODS}

\subsection{Materials}

All the reagents used were of analytical grade (Analar) and all the glassware and containers used were washed with liquid detergent first, rinsed with $20 \%(\mathrm{v} / \mathrm{v})$ nitric acid and finally rinsed with deionised water. The containers and glassware were kept in an oven at $105^{\circ} \mathrm{C}$ until needed. Deionised water was used throughout the work.

\subsection{Description of the Study Area}

The study was conducted in katsina, Northwestern region of Nigeria in April, 2015. Katsina town is bordered to the north-east by Kaita, Jibia and Batsari to the North-west, Batagarawa to south and Mani local Government Areas to the east [11]. It is located at $12.59^{\circ} \mathrm{N}$ and $7.36^{\circ} \mathrm{E}$ at an elevation of 464 meters above sea level. The mean annual maximum and minimum temperatures are $33.2^{\circ} \mathrm{C}$ and $18.7^{\circ} \mathrm{C}$ respectively and the average relative humidity is $60 \%$ with mean annual rainfall of $600 \mathrm{~mm}$ [12].

\subsection{Sampling and Sample Treatment}

\subsubsection{Soil sampling}

Stratified random sampling method was used as follows; each sampling area (the four cardinal points) was divided into seven smaller units and from each unit; seven (7) samples were collected randomly at a depth of $15 \mathrm{~cm}$, mixed and homogenized. The representative samples were obtained using cone and quartered method. The samples were transported to the laboratory for analysis in clean polythene bags [13]. The sampling areas were labeled as follows:

$$
A=\text { East, } B=\text { West } C=\text { North and } D=\text { South. }
$$

\subsubsection{Sample treatment and analysis}

Soil was air dried for 5 days. Foreign and nonsoil materials were removed and the soil was crushed using pestle and mortar, sieved via 1.5 $\mathrm{mm}$ mesh sieve. One gram of each soil sieved soil was put in a digestion tube. $5 \mathrm{~cm}^{3}$ of conc. $\mathrm{H}_{2} \mathrm{SO}_{4}, 1 \mathrm{~cm}^{3}$ of $60 \% \mathrm{HClO}_{4}$ and $0.5 \mathrm{~cm}^{3} \mathrm{HNO}_{3}$ were added to the sample. The digestion tube were placed in a block digester, heated to $105^{\circ} \mathrm{C}$ until a clear fumes was obtained. The digest was then splashed with distilled water and allowed to cool. After cooling it was filtered into a $50 \mathrm{~cm}^{3}$ volumetric flask and diluted to the mark with distilled water [14]. The filtrate was used for metals analysis using flame Atomic Absorption Spectrophotometer. Physico-chemical parameters $(\mathrm{pH}$, Organic matter, moisture and cation exchange capacity) and mineral elements (nitrogen, potassium and phosphorus) were determined according to Radojevic and Bashkin [14].

\subsection{Statistical Analysis}

Data obtained were statistically analyzed using one-way analysis of variance (ANOVA) with SPSS version 10.0 statistical packages and reported as mean \pm standard error of mean of three replicate analyses.

\section{RESULTS AND DISCUSSION}

The results for physicochemical parameters and mineral elements in the soil are determined and presented in Table 1. Results are expressed as mean \pm standard error of mean of triplicate analysis.

\section{$3.1 \mathrm{pH}$}

The $\mathrm{pH}$ value of the soil (Table 1) indicated that the soil in the entire samples site were mildly basic in nature. $\mathrm{pH}$ is one of the most important parameter that serve as an index for pollution. Its a term used universally to describe the intensity of acidic or alkaline nature of the substances. All the soil samples investigated in the present study are alkaline. The $\mathrm{pH}$ value of soil samples varied between 7.11-7.22 which is an indication of the alkalinity of the soil.

\section{$3.2 \%$ CEC}

The total number of cations a soil can hold or its total negative charge is the soil's cation exchange capacity. The percentage cation exchange capacity (CEC) represents the total exchangeable cation held within the soil. In the present study, the CEC ranges between 4.46 to 5.84 which are lower when compared to the $19.2 \%$ and $27.22 \%$ reported by Zauro et al. [15] and Nigussie et al. [16] respectively. 


\subsection{Organic Matter (OM)}

Soil organic matter is a principal factor that affects the heavy metal distribution in soil [17]. Increase in soil organic matter content lead to elevation of soil adsorption capacity hence enhancing the accumulation of trace metals. Organic matters can therefore be considered as one of the medium through which heavy metals are incorporated into the soil. Soil in all the sampling points generally contained low organic matter content with the highest being at sampling point A $(0.798 \pm 0.00 \%)$ with the least value $(0.080 \pm 0.01)$ observed in sample $C$. The percentage OM of the soil showed that it falls within the range of low fertility class. This low OM value could be due to low humus content of the soil [18]. The obtained OM values were lower than the reported value by Inobeme et al. [17] in similar work.

\subsection{Moisture}

The percentage moisture content in all the samples is low. This could be attributed to the time of sampling (April) which is dry season. The moisture content value ranges from $2.0 \%$ to $6.0 \%$. It is clear from the result that sample D have highest moisture content than samples $A, B$ and $\mathrm{C}$. The obtained results in this study are low when compared with the reported moisture content in soil of Katol Taluka District Nagpur in India [19].

\subsection{Mineral Elements}

The exchangeable $\mathrm{Na}, \mathrm{K}, \mathrm{Ca}$ and $\mathrm{Mg}$ were low in all the samples. This is due to the low values of CEC in all the samples. The only element that affects sodium levels in the soil is potassium. When sodium percentage is higher than potassium then there is often trouble on the horizon from soil health and crop productivity point of view [20]. The highest content of $K$ of $11.80 \mathrm{mg} / \mathrm{kg}$ was found in sample $\mathrm{D}$ compared with the $2.20 \mathrm{mg} / \mathrm{kg}$ found in sample C. Table 1 showed that the $\mathrm{Na}$ concentration of $0.24 \mathrm{mg} / \mathrm{kg}$ was obtained in the sample (D) with highest value of $\mathrm{K}$. Ca and $\mathrm{Mg}$ analysed in the present study are shown in Table 1. The no difference was observed in the amount of $\mathrm{Ca}$ between samples $A, B$ and $D$. For $M g$ the concentration varies with in the samples. Even though, all the samples showed low concentration compared to what was reported by Joel and Amajuoyi [9] in similar work.

Table 1. Physicochemical parameters (CEC, moisture, $\mathrm{pH}$ and organic matter) and mineral elements of the soil

\begin{tabular}{lllll}
\hline Parameters & \multicolumn{4}{c}{ Samples } \\
\cline { 2 - 5 } & A & B & C & D \\
\hline $\mathrm{pH}$ & $7.20 \pm 0.02$ & $7.12 \pm 0.10$ & $7.14 \pm 0.04$ & $7.11 \pm 0.40$ \\
Moisture $(\%)$ & $2.0 \pm 0.10$ & $1.5 \pm 0.2$ & $1.5 \pm 0.0$ & $6.0 \pm 0.6$ \\
$\mathrm{CEC}(\%)$ & $5.34 \pm 0.50$ & $5.36 \pm 0.42$ & $5.20 \pm 0.01$ & $5.06 \pm 0.60$ \\
Organic Matter $(\%)$ & $0.798 \pm 0.00$ & $0.140 \pm 0.70$ & $0.080 \pm 0.01$ & $0.120 \pm 0.20$ \\
$\mathrm{Na}(\mathrm{mg} / \mathrm{kg})$ & $1.56 \pm 0.03$ & $0.86 \pm 0.00$ & $0.16 \pm 0.10$ & $0.24 \pm 0.02$ \\
$\mathrm{~K}(\mathrm{mg} / \mathrm{kg})$ & $3.94 \pm 0.05$ & $4.42 \pm 0.20$ & $2.20 \pm 0.00$ & $11.80 \pm 0.60$ \\
$\mathrm{Ca}(\mathrm{mg} / \mathrm{kg})$ & $1.35 \pm 0.01$ & $1.35 \pm 0.30$ & $1.15 \pm 0.04$ & $1.35 \pm 0.10$ \\
$\mathrm{Mg}(\mathrm{mg} / \mathrm{Kg})$ & $0.95 \pm 0.20$ & $1.25 \pm 0.03$ & $0.70 \pm 0.10$ & $1.05 \pm 0.01$ \\
\hline
\end{tabular}

Table 2. Concentration of metals analyzed in $(\mathrm{mg} / \mathrm{kg})$ in the soil

\begin{tabular}{llllll}
\hline Samples & \multicolumn{4}{c}{ Metal concentration $(\mathbf{m g} / \mathbf{k g})$} \\
\cline { 2 - 6 } & $\mathbf{C d}$ & $\mathbf{C r}$ & $\mathbf{M n}$ & $\mathbf{Z n}$ & $\mathbf{P b}$ \\
\hline $\mathrm{A}$ & $0.412 \pm 0.030$ & $3.250 \pm 0.01$ & $1.931 \pm 0.00$ & $1.186 \pm 0.002$ & $\mathrm{ND}$ \\
$\mathrm{B}$ & $0.929 \pm 0.040$ & $4.187 \pm 0.002$ & $2.289 \pm 0.100$ & $0.914 \pm 0.001$ & $\mathrm{ND}$ \\
$\mathrm{C}$ & $0.853 \pm 0.010$ & $0.642 \pm 0.050$ & $\mathrm{ND}$ & $1.530 \pm 0.002$ & $\mathrm{ND}$ \\
$\mathrm{D}$ & $\mathrm{ND}$ & $\mathrm{ND}$ & $\mathrm{ND}$ & $1.450 \pm 0.005$ & $\mathrm{ND}$ \\
US EPA & 70 & 230 & $\mathrm{NA}$ & 23,600 & 400 \\
\hline \multicolumn{5}{c}{ Key: $N D=$ Not detected } \\
\end{tabular}


The results of the heavy metals $(\mathrm{Cd}, \mathrm{Cr}, \mathrm{Mn}$, $\mathrm{Zn}$ and $\mathrm{Pb})$ concentration $(\mathrm{mg} / \mathrm{kg})$ analysed in the present study is presented in Table 2.

Cadmium is naturally non-essential toxic element and it interferes with the metabolism of some essential elements such as zinc, calcium and iron. The concentration of $\mathrm{Cd}$ was found in the range of $0.382-0.969 \mathrm{mg} / \mathrm{kg}$ with the highest value of $0.929 \pm 0.040 \mathrm{mg} / \mathrm{kg}$ observed in sample $\mathrm{B}$. The $\mathrm{Cd}$ was not detected in sample $D$. The result in this work is higher than the ranges of 0.00-0.07 $\mathrm{mg} / \mathrm{kg}$ reported in soil around paint industries in Kaduna [16] and far below the $70 \mathrm{mg} / \mathrm{kg}$ recommended for clean up by US EPA [21].

The concentration of Chromium in the study area ranged from $0.642 \pm 0.050$ to $4.187 \pm 0.002 \mathrm{mg} / \mathrm{kg}$ (Table 2) and in sample $\mathrm{D}$ the $\mathrm{Cr}$ was not detected. Despite the low concentration of $\mathrm{Cr}$ recorded in the present study in all the samples compared to the $230 \mathrm{mg} / \mathrm{kg}$ and $154.8 \mathrm{mg} / \mathrm{kg}$ recommended by US EPA for soil that requires clean up and reported by Krishna and Govil, [22] respectively in soil around Pali Industrial Area, India. The presence of this metal is attributed to the use of fossil fuel and emission from the vehicular movement. Other factor considered for the present of $\mathrm{Cr}$ is smelting process [23] near the sampling area (Dana Steel Company).

$\mathrm{Mn}$ is one of the commonly found elements in the lithosphere. The concentration of $\mathrm{Mn}$ found in the present study ranges from 1.931 to $2.389 \mathrm{mg} / \mathrm{kg}$ (Table 2). The $\mathrm{Mn}$ was not detected in samples $C$ and $D$ and this could be due to the fact that the amount of targeted element is below the detection limit of the machine or completely absent. The $\mathrm{Mn}$ content found in the present work is far below the $339 \mathrm{mg} / \mathrm{kg}$ reported in the literature [24].

Zinc is a metal whose sources in industrial locations are usually anthropogenic [23]. The main anthropogenic sources of $\mathrm{Zn}$ are related to the non-ferric metal industry and agricultural practice. Zinc is a very readily mobile element. Though relatively non toxic, high doses of $\mathrm{Zn}$ show toxic and carcinogenic effects and result in neurologic and hematological complications, hypertension, and kidney and liver function disorders. The concentration of $\mathrm{Zn}$ in all the samples area is very negligible when compared with the 23,600 $\mathrm{mg} / \mathrm{kg}$ suggested by US EPA for soil requiring clean up [21].

Lead was not detected in all the samples despite the fact that the sampling areas lie near the major road. Another reason could be that the concentration is below the detection limit of the AAS.

\section{CONCLUSION}

In this work we investigated physicochemical parameters and some heavy metal contents in soil around Dana Steel Company Katsina. The results obtained showed that the soil of the study area is mildly basic/alkaline and of low fertility. Other parameters such as CEC, $\mathrm{Na}, \mathrm{K}, \mathrm{Ca}$ and $\mathrm{Mg}$ ions were all low in the soil. Similarly, the results also showed that all the metals analysed were present in samples A, B and C, but only $\mathrm{Zn}$ were detected in sample $\mathrm{D}$. The $\mathrm{Pb}$ was not detected in all the samples. The amount of metals obtained in this work showed that the area was not polluted as they metals contents were all below the value recommended by US EPA for soil that require clean up. Furthermore, there is need for further study to ascertain the level of contamination by other pollutants and the biological sustainability of the soils in the near future.

\section{COMPETING INTERESTS}

Authors have declared that no competing interests exist.

\section{REFERENCES}

1. Gajbhiye SP, Bhalerao SA. A study of physico-chemical and some heavy metal pollutants in soil from the industrial area of Thane-Belapur MIDC Region, Maharashtra State, India. Research Journal of Chemical and Environmental Sciences. 2016;4(1): 43-52.

2. Zauro SA, Lawal AM, Umar KJ, Sani YM, Abubakar I. Assessment of selected heavy metals in soil and Cassia occidentalis in rural area of Jega local government, Kebbi State, Nigeria. International Journal of Scientific and Research Publications. 2015;5(10):1-6. 
3. Tchounwou PB, Yedjou CG, Patlolla AK, Sutton DJ. Heavy metals toxicity and the environment, EXS. 2012;101:133-164. DOI: $10.1007 / 978-3-7643-8340-4 \_6$

4. Leyval C, Turnau K, Haselwandter K. effect of heavy metal pollution on mycorrhizal colonization and function: Physiological, ecological and applied aspects. Mycorrhiza. 1997;7(3): 139-153.

DOI: $10.1007 /$ s005720050174

5. Shaheen SM, Rinklebe J, Rupp H, Meissner R. Temporal dynamics of pore water concentrations of $\mathrm{Cd}$, $\mathrm{Co}, \mathrm{Cu}, \mathrm{Ni}$, and $\mathrm{Zn}$ and their controlling factors in a contaminated flood plain soil assessed by undisturbed groundwater lysimeters. Environmental Pollution. 2014;191:223231.

DOI: 10.1016/j.envpol.2014.04.035

6. Panda SK, Choudhury S. Chromium stress in plants in toxic metal in plants. Brazilian Journal of Plant Physiology. 2005;17(1): 95-102.

7. White PM, Wolf DC, Thomas GJ, Reynolds CM. Phytoremediation of alkylated polycyclic aromatic hydrocarbons in an oilcontaminated soil. Water, Air and Soil Pollution. 2006;169:207-220.

8. Galadima A, Garba ZN. Heavy metals pollution in Nigeria. Causes and consequences. Elixir Pollution. 2012;45: 7917-7922.

9. Joel OF, Amajuoyi CA. Determination of selected physicochemical parameters and heavy metals in a drilling cutting dump site at Ezeogwu-Owaza, Nigeria. Journal of Applied Science and Environmental Management. 2009;13(2):27-31.

10. Tijjani N, Dioha IJ, Alhassan B, Eleri, Al, Lawal AM, Muhammad I. Determination of some heavy metals in soil samples obtained from Rimi local Government in Katsina State, Nigeria. Chemistry and Materials Research. 2013;3(5):27-30.

11. Shehu J. A social and political history of Katsina metropolis, 1960-2007. Journal of the Historical Society of Nigeria. 2012;21: 196-202.

12. Ladan SI. Assessment of waste management and control strategies in Katsina metropolis, Katsina state, Nigeria. JORIND. 2013;11(1):189-195.
13. Radojevic M. Bashkin VN. Practical environmental analysis, $1^{\text {st }}$ edn, Rsc Publishing, Cambridge, UK; 1999.

14. Radojevic M. Bashkin VN. Practical environmental analysis, $2^{\text {nd }}$ edn, Rsc Publishing, Cambridge, UK; 2006.

15. Zauro SA, Dabai MU, Tsafe Al, Umar KJ, Lawal AM. Extent of some heavy metals contamination in soil of farmlands around Sokoto metropolis. European Scientific Journal. 2013;9(3):30-36.

16. Nigussie A, Kissi E, Misganaw M, Ambaw G. Effect of biochar application on soil properties and nutrient uptake of lettuces (Lactuca sativa) grown in chromium polluted soils. American-Eurasian Journal of Agriculture \& Environmental Sciences. 2012;12(3):369-376.

17. Inobeme A, Ajai Al, lyaka YA, Ndamitso $M$, Uwem B. Determination of physicchemical and heavy metal content of soil around paint industries In Kaduna. International Journal of Scientific \& Technology Research. 2014;3(8):221-225.

18. Raman N, Sathiyanarayanan D. Physicochemical characteristics of soil and Influence of cation exchange capacity of soil in and around Chennai. Rasayan Journal of Chemistry. 2009;2(4):875-885.

19. Borkar AD. Studies on some physicochemical parameters of soil samples in Katol Taluka District Nagpur (MS), India. Research Journal of Agriculture and Forestry Sciences. 2015; 3(1):16-18.

20. Ranade-Malvi U. Interaction of micronutrients with major nutrients with special reference to potassium. Karnataka Journal of Agricultural Sciences. 2011; 24(1):106-109.

21. US EPA. Supplemental guidance for developing soil screening levels for superfund sites. Office of Solid Waste and Emergency Response, Washington, D.C; 2002.

Available:http://www.epa.gov/superfund/he alth/conmedia/soil/index.htm

22. Krishna AK, Govil PK. Heavy metal contamination of soil around Pali industrial area, Rajasthan, India. Environmental Geology. 2004;47:38-44.

DOI: 10.1007/s00254-004-1124-y

23. Krishna AK, Govil PK. Soil contamination due to heavy metals from an industrial 
area of Surat, Gujarat, Western India, Environmental Monitoring and Assessment. 2007;124:263-275.

DOI: 10.1007/s10661-006-9224-7

24. Rahman $\mathrm{SH}$, Khanam D, Adyel TM, Islam MS, Ahsan MA, Akbor MA. Assessment of heavy metal contamination of agricultural soil around Dhaka Export Processing Zone (DEPZ), Bangladesh. Implication of seasonal variation and indices. Applied Sciences. 2012;2:584-601.

DOI: 10.3390/app2030584

(c) 2017 Zauro et al.; This is an Open Access article distributed under the terms of the Creative Commons Attribution License (http://creativecommons.org/licenses/by/4.0), which permits unrestricted use, distribution, and reproduction in any medium, provided the original work is properly cited.

Peer-review history:

The peer review history for this paper can be accessed here: http://sciencedomain.org/review-history/19333 